\title{
Comparison of antimicrobial potentiality of the purified terpenoids from two moss species Thuidium tamariscellum (C. Muell.) Bosch. \& Sande-Lac and Brachythecium buchananii (Hook.)A. Jaeger
}

\begin{abstract}
Microbicidal resistant pathogens have increased tremendously; meanwhile the search for the new antibiotics has reduced. Herbals are treasure islands of many phytochemicals with potential biological features. Bryophytes are the oldest lineage of land plants and mostly unexplored in terms of their medicinal importance. This study targets to extract terpenoids, its purification, fractionation and evaluation of microbicidal potentialities from Thuidium tamariscellum and Brachythecium buchananii against E. coli, Staphylococcus aureus, Pseudomonas aeroginosa and Streptococcus mutans and Bacillus cereus. Fungal species includes Aspergillus flavus and Candida albicans. The analysis include susceptibility determination test, effect of the extract on cell membrane integrity and fungal spore inhibition assay. It was found that the T. tamariscellum terpenoid extract was more effective than the $B$. buchananii extract. T. tamariscellum terpenoid extract displayed the significant minimum inhibitory concentration and minimum killing concentration i.e., the values ranged from 0.0625 to $0.125 \mathrm{mg} / \mathrm{mL}$ and 0.25 to $0.5 \mathrm{mg} / \mathrm{mL}$ against $S$. aureus and $E$. coli respectively. However, both the moss species showed remarkable antifungal property. Nucleic acid, protein leakage and relative electrolyte conductive \% substantiate the MIC and $\mathrm{MKC}$ values of the bacterial strains. Spore inhibition value increases in proportion to concentration of the extracts which further confirms the fungicidal power. Overall, the terpenoid extract from T. tamariscellum has potent antimicrobial activity and may be a potential source of lead molecules for the future development of microbicidal agents. Further studies are warranted to analyze the morphological deformities using electron microscopy.
\end{abstract}

Keywords: bryophytes, antimicrobial, inhibitory concentration, killing concentration, membrane permeability, spore, terpenoids
Volume 7 Issue 5 - 2018

\author{
Greeshma GM,' Murugan K² \\ 'Deptartment of Botany, University College, India \\ ${ }^{2}$ Deptartment of Botany \& Biotechnology, Govt. Arts College, \\ India
}

Correspondence: Murugan K, Deptartment of Botany \& Biotechnology, Govt. Arts College, Thiruvananthapuram, Kerala, India, Email harimurukan@gmail.com

Received: July 03, 2017 | Published: September 14, 2018

\section{Introduction}

Mosses are small nonvascular spore bearing land plants distributed throughout the temperate and tropical parts of the world. There are approximately 14,500 species which constitutes around $75 \%$ among the bryophyte species. They are commonly found in moist shady locations. The species originated as early as the Permian period and more than 100 species have been recorded from fossils of the Paleogene and Neogene periods. ${ }^{1}$ Mosses perform various important ecological roles such as filtering and retaining water, stabilizing the ground and removing $\mathrm{CO}_{2}$ from the atmosphere. Many moss species were reported to possess unique natural products or secondary metabolites such as phenols, flavonoids, alkaloids, terpenoids and other aromatic compounds with therapeutic potentialities. Historically, the therapeutic features of herbals are the concept of doctrine of signatures. Bryophytes form the basement of Chinese medicinal treatment. For example, liverwort was used to cure hepatic disorders, Polytrichum commune induce women's hair growth. Gaddi tribes of Himachal Pradesh, used Plagiochasma appendiculatum for treating skin diseases, Targionia hypophylla used by Irular tribec of Attappady to cure skin diseases due to resembles of thallus to the warty surface of the diseased region and Frullania ericoides, liverwort for hair-related applications by tribal people of South India. Species like Sphagnum, Barbula, Bryum, Octeblepharum and Fontinalis are used to treat different diseases, including cardiovascular diseases, inflammation, fever, lung diseases, infections, wounds and skin prone diseases. ${ }^{1}$ The aqueous extract of the three mosses like Brachythecium rutabulum, Calliergonella cuspidate and Hypnum mammillatum showed potent antioxidant activity. ${ }^{2,3}$ The species like Polytrichum commune were used as antipyretic and anti-inflammatory agent and boiled with tea for treating the cold. Rhodobryum giganteum is another species traditionally used to treat diseases like cardiovascular diseases or angina. ${ }^{1}$

The moss Plagiochilla beddomei possesses significant antioxidant activity. ${ }^{4}$ The moss Physcomitrella patens under axenic condition produces a tetracyclic diterpene, namely $16 \alpha-$ hydroxykaurane (16 $\alpha$-hydroxy-ent-kaurane, Kaurenol, $\mathrm{C}_{20} \mathrm{H}_{34} \mathrm{O} .{ }^{1} \alpha$ and $\beta$ pininealloromadendrine from Plagiochilla stevensoniana were useful as anticancer and antimicrobial compounds. ${ }^{5}$ Mosses retard the growth of cancer cells in in vitro culture studies. The plant derived natural products occupy an important place in the area of cancer chemotherapy because of minimal side effects. Polytrichum commune plays significant role especially for the therapy of lymphocytic leukemia. $^{5}$ 
Phenolic compounds isolated from Atrichum, Dicranum, Mnium, Polytrichum and Sphagnum spp. were reported to possess antimicrobial properties. The antimicrobial activity for three moss species Eurhynchium angustirete, Rhytidia delphussquarrosus and Rhodo bryumroseum was validated by Nikolajeva. ${ }^{6}$ Thuidium gratum, Ectropothecium aeruginosum, Sematophyllum caespitosum, Stereophyllum radiculosum, Babulalam berenensis, Campilopusa spericuspis and Calympereserosumlam berenensis, Campilopusa spericuspis and Calympereserosum were proved for their potential antimicrobial properties. ${ }^{7}$ The moss Atricum undulatum possesses strong antifungal activity against Aspergillus versicolor and A. fumigates. ${ }^{8}$

The outbreak of multiple antibiotic tolerant Gram-positive, Gramnegative bacteria and fungal pathogens in hospitals and community centers requires new approaches for fast diagnosis and treatment. Prioritization of infectious agents for research and development is need of the hour that defines the impact of pathogens on human health. Ranking antibiotic-resistant organisms in order to direct research and development requires an accurate identification and integration of mass knowledge that explains the issue of antimicrobial resistance organisms in terms of microbiological, epidemiological and clinical ways.

Terpenoids group of isoprenoids are diverse group of natural products derived from the five carbon isoprene units. Based on the number of isoprene units they are classified into hemiterpenoids (C5), monoterpenoids (C10), sesquiterpenoids (C15), diterpenoids (C20), sesterterpenids (C25) and triterpenoids (C30). Terpenoids possess a wide range of medicinal properties for the treatment of various illnesses such as cancer, malaria, inflammation and various infectious diseases (viral and bacterial).

Therefore, the present study was aimed to analyze the antimicrobia activities of the purified terpenoid extracts from two moss species Thuidium tamariscellum and Brachythecium buchananii against Gram positive and Gram negative bacteria and selected fungal strains. Parallely the mode of action of the terpenoid in terms of their microbicidal power was also analyzed.

\section{Materials and methods}

\section{Plant materials}

Brachythecium buchananii and Thuidium tamariscellum were belongs to Brachytheciaceae and Thuidiaceae of Musci. Both the species grow as epiphytes on trunks of trees and also on moist rocky and shady surfaces of high altitude regions. The identity of the two species were confirmed by floras and authenticated by comparing with the herbarium of University of Calicut. Voucher specimens were deposited in the herbarium of Department of Botany, University College, Thiruvananthapuram UBH 630 and UBH 631.

\section{Column chromatography and GC-MS analysis}

The crude methanolic extract of the mosses were purified using silica gel column chromatography and eluted with petroleum ether: ethyl acetate as solvent combinations. The different eluted column fractions were subsequently quantified for the presence of terpenoid as per the method described by Ferugson. ${ }^{9}$ The purified fraction was subjected to GC-MS analysis. The chromatogram obtained containing a pool of compounds and the mass spectrum of the unknown components were compared with the spectrum of the known components available with the NIIST library.

\section{Antibacterial assay}

Test microorganisms: E. coli (ATCC 25922), Staphylococcus aureus (ATCC 25923), Pseudomonas aeroginosa (ATCC 27853), Streptococcus mutans (MTCC 890) and Bacillus subtilius (ATCC 6633).

Petriplates containing $20 \mathrm{ml}$ Muller Hinton agar medium were seeded with bacterial culture of E. coli, Pseudomonas aeroginosa, Streptococcus mutans, Bacillus subtilius and Staphylococcus aureus (growth of culture adjusted according to McFards Standard, $0.5 \%$. Wells of approximately $10 \mathrm{~mm}$ was bored using a well cutter and different concentrations of terpenoid extracts such as $0.25 \mathrm{mg} /$ $\mathrm{mL}, 0.5 \mathrm{mg} / \mathrm{mL}, 0.75 \mathrm{mg} / \mathrm{mL}, 1.0 \mathrm{mg} / \mathrm{mL} 1.5 \mathrm{mg} / \mathrm{mL}$ and $2.0 \mathrm{mg} / \mathrm{mL}$ were added. The plates were then incubated at $37^{\circ} \mathrm{C}$ for $24 \mathrm{~h}$. The bactericidal activity was assayed by measuring the diameter of the inhibition zone $(\mathrm{mm})$ formed around the well. ${ }^{10}$ Streptomycin was used as a positive control. ${ }^{10}$

\section{Antifungal assay}

Test organisms were Aspergillus flavus (ATCC 16404) and Candida albicans (ATCC 10231). Freshly prepared potato dextrose agar (PDA) plates and were swabbed with overnight grown fungal species such as Aspergillus flavus and Candida albicans. Wells of approximately $10 \mathrm{~mm}$ was bored using a well cutter and different concentrations of terpenoid extracts such as $0.25 \mathrm{mg} / \mathrm{mL}, 0.5 \mathrm{mg} / \mathrm{mL}, 1.0 \mathrm{mg} / \mathrm{mL} 1.5 \mathrm{mg} /$ $\mathrm{mL}$ and $2.0 \mathrm{mg} / \mathrm{mL}$ were added. The zone of inhibition was measured after overnight incubation at room temperature and compared with that of standard antimycotic clotrimazole. ${ }^{10}$

Minimal inhibitory concentration (MIC) was determined by using two-fold serial dilution method of Eloff ${ }^{11}$ with some modifications. Briefly, the suspensions of bacterial strains prepared from overnight broth cultures, were adjusted to the required microbial density (about $10^{7} \mathrm{CFU} / \mathrm{mL}$ ). Terpenoid extracts was dissolved in DMSO, then twofold serial dilutions were made in a concentration ranging from 0.0625 to $2.5 \mathrm{mg} / \mathrm{mL}$ in $10 \mathrm{~mL}$ sterile test tubes. A $50 \mu \mathrm{L}$ suspension of the strains was added into the tube. The tube containing only broth and the strain was the negative control. The MIC was determined as the lowest concentration of the extract that demonstrated no visible growth in tubes after $24 \mathrm{~h}$.

Minimal killing concentration (MKC) was analyzed by subculturing the different doses that had no visible growth. $100 \mu \mathrm{L}$ from each dilution was inoculated on the surface of freshly made nutrient agar plates and incubated for $24 \mathrm{~h}$ at $37^{\circ} \mathrm{C}$. The minimum concentration that had no detectable growth on agar media after $24 \mathrm{~h}$ incubation was noted as MKC.

\section{Permeability of bacterial membrane}

The bacterial membrane permeability was expressed in the relative electric conductivity according to the protocol of Diao et al. ${ }^{12}$ The bacterial strains was separated by centrifuging at $5,000 \times g$ for $10 \mathrm{~min}$, and then washed with $5 \%$ glucose until the electric conductivity was approximately near to that of $5 \%$ glucose, which suggests the case of isotonic bacteria. The electric conductivity was recorded by an electrical conductivity meter. Terpenoid extracts at three different 
doses (control, $1 \times \mathrm{MIC}$, and $2 \times \mathrm{MIC}$ ) were added into $5 \%$ glucose; the electric conductivity of the mixtures was measured and marked as $\mathrm{L}_{1}$. Then different doses of terpenoid extracts (control, $1 \times \mathrm{MIC}$, and $2 \times \mathrm{MIC}$ ) were added into the isotonic bacteria, respectively. After completely mixing, the samples were incubated at $37^{\circ} \mathrm{C}$ for $10 \mathrm{~h}$; the conductivity was measured per $2 \mathrm{~h}$; it was marked as $\mathrm{L}_{2}$. The conductivity of bacteria in $5 \%$ glucose treated in boiling water for 5 min was used as the control which was marked as $\mathrm{L}_{0}$. The permeability of cell membrane is quantified using

$$
\text { Relative electric conductivity }(\%)=100 \times\left(\mathrm{L}_{2}-\mathrm{L}_{1}\right) / \mathrm{L}_{0}
$$

\section{Bacterial membrane integrity}

The bacterial cell membrane integrity was analyzed by the protocol of Du et al., ${ }^{13}$ with marginal modifications. $100 \mathrm{~mL}$ of working culture of bacteria was centrifuged at $3000^{\circ} \mathrm{g}$ for $15 \mathrm{~min}$. The bacterial cells were collected, washed thrice and re-suspended in $0.1 \mathrm{M} \mathrm{pH} 7.4$ phosphate buffer solutions. $100 \mathrm{~mL}$ buffer treated bacterial culture was incubated with different doses of terpenoid extracts (control, MIC and $2 \times \mathrm{MIC}$ ) at $37^{\circ} \mathrm{C}$ for $6 \mathrm{~h}$ under agitation. Then $25 \mathrm{~mL}$ of the aliquots were collected and centrifuged at $11,000 \times \mathrm{g}$ for $5 \mathrm{~min}$. The protein content in the supernatants was quantified by the Bradford method. ${ }^{14}$

\section{Analysis on nucleic acids leakage}

Propidium iodide (PI) is a dye that binds effectively to nucleic acids. The dye is not capable of intrude in to viable cells suggesting it as a marker to analyze the effects of drugs on bacterial membranes leakage. The selected bacterial cells were suspended in $0.9 \%$ saline medium $\left(\mathrm{OD}_{600}=1.5\right)$. The suspensions were further exposed to terpenoid extracts at doses of the MIC and $\times 2$ MIC in duplicate for $10 \mathrm{~min}$. The bacteria $(1 \mathrm{~mL})$ were centrifuged for $1 \mathrm{~min}$ at $11000 \times \mathrm{g}$. The pellet was washed with $1 \mathrm{~mL} 0.9 \%$ saline solution. $3 \mu$ l of PI was added to each sample and the solution was mixed thoroughly. The samples were kept in the dark for $10 \mathrm{~min}$. Fluorescence was recorded at excitation and emission at $544 \mathrm{~nm}$ and $612 \mathrm{~nm}$, respectively, using an $f$ max microplate spectrofluorometer. The controls used were non treated cells, 3\% DMSO and streptomycin.

\section{Effect of terpenoid on spore germination}

The effect of different doses of the terpenoid extracts of $B$. buchananii and T. tamariscellum on spore germination of C. albicans and A. flavus was studied. $1 \mu 1$ of each extract at different doses $(0.125 \mathrm{mg} / \mathrm{mL}, 0.25 \mathrm{mg} / \mathrm{mL}, 0.5 \mathrm{mg} / \mathrm{mL}$ and $1.0 \mathrm{mg} / \mathrm{mL})$ was poured into $50 \mathrm{ml}$ conical flasks and $9 \mathrm{ml}$ of the PDA was added to each conical flask which gave PDA-extract mixture with corresponding extract concentration. These doses were used to study spore germination of the isolates. Spore suspensions of C. albicans and A. flavus containing 20-30 spores per microscopic field was prepared from 7 days old cultures of isolates. One drop of spore suspension was put in a glass slides containing a drop of different doses of terpenoid extract. Hence slides were kept in moist chamber prepared by putting two folds of filter paper in both side of the Petri dishes were incubated at $28^{\circ} \mathrm{C}$ for $24 \mathrm{~h} .{ }^{15}$ The spore germination \% was recorded by the method of Salhi et al. ${ }^{16}$

$$
\text { Percent spore germination }=\frac{\text { Number of spore germinated }}{\text { Total number of spores }} \times 100
$$

\section{Statistical analysis}

Statistical analyses were attempted using One-Way analysis of variance (ANOVA) of SAS 8.0 software to analyze the difference of DIZ, MIC, MKC, relative electric conductivity, the concentration of leaching nucleic acids, proteins, spore inhibition among control, $1 \times \mathrm{MIC}$ and $2 \times$ MIC groups. The statistically significant level was set as 0.05 .

\section{Results and discussion}

\section{GC-MS analysis of the moss species}

The $100 \%$ PE column eluted fraction of $T$. tamariscellum and Brachythecium buchananii showed a single band on TLC. GC-MS analysis yielded 15 terpenoids in T. tamariscellum such as $\alpha$-cubebene, caryophyllene, 1-tetradecene, dodecanal, tetradecane, heptadecane, pentadecane, hexadecane, eicosane,octadecane, nonadecane, heneicosane, docosane, pentacosane and hexacosanes. Similarly, GCMS analysis of Brachythecium buchananii displayed 5 compounds such as hexadecane, hexadecanoic acid, octadecane, heneicosane and tetracosane.

Martins et al., ${ }^{17}$ reported that the essential oil of Cordia species showed a pool of terpenoids including caryophyllene and was effective against the treatment of buccal and inflammatory pathogens. The petroleum ether extract of Citrus medica seeds an ethanomedicinal plant was used for the treatment of piles, inflammation showed the presence of $\mathrm{n}$-hexadecanoicacid, heneicosane, nonadecane and tetracosane. ${ }^{18}$.

\section{Antimicrobial activity}

Microbiologists documented the efficacy of herbal extracts and their phytochemicals as microbicidal agents to inhibit growth of bacteria. Some phytochemists have recorded that microbicidal agents like terpenoid of phenolic group interact with enzymes and biomolecules of the microbial cell membrane causing its derailment to disperse a flux of protons towards cell exterior which induces cell death or block enzymes necessary for metabolism.

The antimicrobial activity of various doses $(0.25 \mathrm{mg} / \mathrm{mL}, 0.5 \mathrm{mg} /$ $\mathrm{mL}, 0.75 \mathrm{mg} / \mathrm{mL}, 1.0 \mathrm{mg} / \mathrm{mL}, 1.5 \mathrm{mg} / \mathrm{mL} 2.0 \mathrm{mg} / \mathrm{mL}$ ) of terpenoid extracts of $B$. buchananii and T. tamariscellum against E. coli, Pseudomonas aeroginosa, Streptococcus mutans, Bacillus subtilius and Staphylococcus aureus were qualitatively and quantitatively analyzed by the presence of inhibition zones. As presented in Table $\mathbf{1}$, the diameter of inhibitory zone (DIZ in $\mathrm{mm}$ ) values for all the strains increased significantly $(P<0.05)$ along with the increasing concentration of the extract. Remarkable inhibitory zone values were noticed with Staphylococcus aureus followed by E. coli i.e., $26.1 \pm 0.65$ and $17.3 \pm 0.16 \mathrm{~mm}$ respectively treated with terpenoid extracts of T. tamariscellum. However, B. buchananii also showed a more or less similar trend but with lesser values. Most of the strains were susceptible against the terpenoids except Streptococcus mutans and Bacillus subtilius (resistant forms).

Laura et al. ${ }^{19}$ demonstrated that the moss species Climacium dendroide and Polytrichum commune possess strong antibacterial activity against the bacterial strains such as Bacillus cereus, Staphylococcus aureus and E. coli. Hylocomium splendens and Pleurozium schreberi showed significant antibacterial activity against 
Pseudomonas aeruginosa (inhibition zone diameter $12 \mathrm{~mm}$ ) ${ }^{20}$ Pejin et al., ${ }^{20}$ reported that Climacium dendroides, Ptilium crista-castrensis, Rhytidiadelphus triquetrus and Sphagnum magellanicum showed strong antibacterial activity against $E$. coli.

Meanwhile, the fungal species such as A. flavus and C. albicans were significantly inhibited by the terpenoid extracts of $T$. tamariscellum (25.9 \pm 0.84 and $22.5 \pm 0.48$ respectively) and B. buchananii $(22.5 \pm 0.85$ and $20.1 \pm 0.04$ respectively) The values were comparable with the synthetic antibiotics streptomycin and clotrimazole. The MIC values for terpenoid extracts from T. tamariscellum were 0.0625 and $0.25 \mathrm{mg} /$ $\mathrm{mL}$ for Staphylococcus aureus and E. coli respectively. In the case of $B$. buchananii the respective values were $0.125 \pm 0.03$ and $0.5 \pm 0.06$ (Table 2).

Weerakkody et al. ${ }^{21}$ commented the mode of classification of microbicidal power into strong activity i.e., DIZ $>20 \mathrm{~mm}$, (moderate $=<20 \mathrm{~mm})$, and weak $=($ DIZ $<12 \mathrm{~mm})$. Similarly, Aligiannis et al. ${ }^{22}$ suggested that MIC value up to $0.5 \mu 1 / \mathrm{mL}$ as strong; moderate if MIC $0.6-1.5 \mu \mathrm{l} / \mathrm{mL}$, and low above $1.5 \mu \mathrm{l} / \mathrm{mL}$. The results of the present study showed that terpenoid extracts displayed strong to moderate antimicrobial activity against the selected strains. It could be attributed to the major components like $\alpha$-cubebene, caryophyllene, 1-tetradecene, dodecanal, tetradecane, heptadecane, pentadecane, hexadecane, eicosane, octadecane, nonadecane, heneicosane, docosane, pentacosane and hexacosanes which seems to increase the permeability of cell membrane or disintegrate the outer membrane of Gram-negative bacteria. MICs of fungal species A. flavus were $0.0625 \pm 0.09$ and $0.125 \pm 0.0234$ against $T$. tamariscellum and $B$. buchananii respectively. The entire spectra of MICs substantiate the zone of inhibition data of the respective strains (Table 2).

Table I Microbicidal activity of purified terpenoid from Thuidium tamariscellum and Brachythecium buchananii determined by agar diffusion assay. Mean \pm SD, $p<0.05$

\begin{tabular}{llllllll}
\hline $\begin{array}{l}\text { Conc. (mg/ml) } \\
\text { T. tamariscellum }\end{array}$ & E. coli & P. aeruginosa & S. mutans & S. aureus & B. subtilis & A. flavus & C. albicans \\
\hline 0.25 & $3.55 \pm 0.03$ & $4.4 \pm 0.02$ & $1.4 \pm 0.08$ & $8.5 \pm 0.09$ & $0.94 \pm 0.07$ & $7.2 \pm 0.03$ & $6.8 \pm 0.51$ \\
0.5 & $5.4 \pm 0.02$ & $6.2 \pm 0.09$ & $2.5 \pm 0.08$ & $11.2 \pm 0.05$ & $1.5 \pm 0.21$ & $9.5 \pm 0.20$ & $10.2 \pm 0.4$ \\
0.75 & $8.9 \pm 0.02$ & $7.1 \pm 0.04$ & $4.6 \pm 0.11$ & $14.5 \pm 0.4$ & $2.2 \pm 0.23$ & $11.3 \pm 0.05$ & $12 \pm 0.02$ \\
1.0 & $12.5 \pm 0.05$ & $8.5 \pm 0.5$ & $6.3 \pm 0.35$ & $20.6 \pm 0.47$ & $4.3 \pm 0.04$ & $17.3 \pm 0.26$ & $15.4 \pm 0.06$ \\
1.5 & $15.4 \pm 0.32$ & $10.6 \pm 0.12$ & $8.9 \pm 0.09$ & $24.7 \pm 1.25$ & $5.9 \pm 0.01$ & $23.8 \pm 0.22$ & $19.8 \pm 0.67$ \\
2.0 & $17.3 \pm 0.16$ & $12.6 \pm 0.21$ & $10.3 \pm 0.08$ & $26.1 \pm 0.65$ & $7.6 \pm 0.01$ & $25.9 \pm 0.84$ & $22.5 \pm 0.48$ \\
Conc. (mg/ml) & E. coli & P. aeruginosa & S. mutans & S. aureus & B. subtilis & A. flavus & C. albicans \\
B. buchananii & $2.8 \pm 0.07$ & $2.7 \pm 0.09$ & $0.4 \pm 0.01$ & $8 \pm 0.02$ & $0.35 \pm 0.09$ & $7.4 \pm 0.03$ & $6.7 \pm 0.07$ \\
0.25 & $4.4 \pm 0.01$ & $3.8 \pm 0.05$ & $0.95 \pm 0.04$ & $10 \pm 0.2$ & $2.0 \pm 0.11$ & $9 \pm 0.08$ & $8 \pm 0.05$ \\
0.5 & $6.5 \pm 0.06$ & $5.3 \pm 0.01$ & $2.0 \pm 0.08$ & $13 \pm 0.08$ & $3.2 \pm 0.03$ & $10.7 \pm 0.2$ & $9.4 \pm 0.04$ \\
0.75 & $10.8 \pm 0.03$ & $9 \pm 0.22$ & $4.8 \pm 0.07$ & $17.6 \pm 0.34$ & $4.3 \pm 0.4$ & $14 \pm 0.1$ & $12.9 \pm 0.02$ \\
1.0 & $13.1 \pm 0.05$ & $12.1 \pm 0.04$ & $7 \pm 0.02$ & $20 \pm 0.54$ & $5.9 \pm 0.1$ & $19.6 \pm 0.05$ & $18 \pm 0.07$ \\
1.5 & $15.4 \pm 0.07$ & $14.1 \pm 0.33$ & $8.8 \pm 0.021$ & $22.4 \pm 1.54$ & $7.6 \pm 0.05$ & $22.5 \pm 0.85$ & $20.1 \pm 0.04$ \\
2.0 & & & & & &
\end{tabular}

Table 2 MIC and MKC of purified terpenoid of Thuidium tamariscellum and Brachythecium buchananii $(\mathrm{mg} / \mathrm{ml})$. Mean $\pm \mathrm{SD}, \mathrm{p}<0.05$

\begin{tabular}{|c|c|c|c|c|}
\hline \multirow[b]{2}{*}{ Organism } & \multicolumn{2}{|c|}{ Thuidium tamariscellum } & \multicolumn{2}{|c|}{ Brachythecium buchananii } \\
\hline & MIC & MKC & MIC & MKC \\
\hline E. $\operatorname{coli}(-)$ & $0.25 \pm 0.04$ & $0.5 \pm 0.05$ & $0.5 \pm 0.06$ & $1.0 \pm 0.02$ \\
\hline P. aeruginosa (-) & $0.50 \pm 0.13$ & $1.0 \pm 0.07$ & $0.75 \pm 0.03$ & $1.50 \pm 0.01$ \\
\hline S. mutans $(+)$ & $2.0 \pm 0.49$ & $4.0 \pm 0.08$ & $2.5 \pm 0.11$ & $5.0 \pm 0.25$ \\
\hline S. aureus $(+)$ & $0.0625 \pm 0.01$ & $0.125 \pm 0.01$ & $0.125 \pm 0.03$ & $0.250 \pm 0.02$ \\
\hline B. subtilis $(+)$ & $2.5 \pm 0.09$ & $5.0 \pm 0.07$ & $0.75 \pm 0.07$ & $1.5 \pm 0.056$ \\
\hline A. flavus & $0.0625 \pm 0.09$ & $0.125 \pm 0.09$ & $0.125 \pm 0.0234$ & $0.25 \pm 0.08$ \\
\hline C. albicans & $0.125 \pm 0.01$ & $0.25 \pm 0.03$ & $0.25 \pm 0.022$ & $0.5 \pm 0.045$ \\
\hline
\end{tabular}


MKC of T. tamariscellum and B. buchananii were in the range of $0.125-5.0 \mathrm{mg} / \mathrm{mL}$ and $0.25-5 \mathrm{mg} / \mathrm{mL}$ respectively, against all tested strains (Table 2). MIC values of terpenoid extracts were significantly $(\mathrm{p}<0.05)$. Similarly the MKCs of $C$. albicans were $0.25 \pm 0.03$ and $0.5 \pm 0.045$ against $T$. tamariscellum and $B$. buchananii respectively. The values were significant at $5 \%$ level.

Irfan et al. ${ }^{23}$ reported that terpenoids from Sphaeranthus indicus L showed strong antimicrobial activity against Escherichia coli and Klebsiella pneumonia. The terpenoids such as beta-sitosterol, alphaamyrin, lupeol, hexacosanoic acid, ceryl alcohol and hexacosane from Trichodeama amplexicaule possess potent microbicial activity against Escherichia coli and A. flavus. ${ }^{2}$

\section{Mode of antibacterial mechanism}

The antibacterial activity of terpenoid extract may be through affecting the external membrane and the cytoplasm. The hydrophobicity of the terpenoid components enables them partition in the lipid fractions of the membranes and also disrupting the mitochondrial structures, altering their functions from permeably. ${ }^{25}$ This in turn, derails the production of biomolecules like DNA, RNA, protein which leads to the death of the cells. ${ }^{26}$ The GC-MS analysis of the terpenoid extracts of the species may attributes the specific mode via disrupting the targets in the cell. ${ }^{27}$

\section{Cell membrane permeability}

Cell membrane potential remarkably regulates the microbial balance and resistance to antibiotics. ${ }^{28}$ Normal physiological conditions of bacterial cells have a negative charge due to the presence of anionic entities like carboxyl and phosphate in the membrane. ${ }^{29}$ Drugs depolarize the membrane pay way for reduction of the membrane potential volume. In the present results, the PI intensity may be directly correlated with the membrane potential. The loss of cell membrane depolarization of bacteria cells may leads to irregular cell metabolic activity and there by death of the bacterial cells.

\section{Nucleic acids leakage}

The fluorescence of propidium iodide (PI) in the bacterial cells after exposure to the T. tamariscellum and B. buchananii extracts was shown in the Figure 1. Against $S$. aureus, the fluorescence of
PI significantly enhanced with the dose of the terpenoid extract. The T. tamariscellum extract caused the high nucleic acids leakage for $S$. aureus i.e., at the MIC $(0.0625 \mathrm{mg} / \mathrm{mL})$ and double the MIC $(0.125 \mathrm{mg} / \mathrm{mL})$, the fluorescence of PI was 2.33 fluorescence units (F/units) and 3.02 F/units, respectively. The fluorescence of PI was lowest in the B. subtilis cells, which was 0.29 and $0.94 \mathrm{~F} /$ units at MIC and $\times 2$ MIC. In E. coli, following exposure to the extract, the fluorescence of PI was $1.54 \mathrm{~F} /$ units and $2.5 \mathrm{~F} /$ units after exposure to the MIC and $\times 2$ MIC respectively. The $B$. buchananii extracts at MIC and double the MIC caused nucleic acid leakage 1.12 and 2F/units in E. coli cells. However, terpenoid extracts showed less efficacy in terms of fluorescence of PI with S. mutans. Untreated cells showed a negligible PI fluorescence of F/units. The same was true for cells treated with DMSO also.

\section{Protein leakage}

B. subtilis and S. mutans cells displayed insignificant protein leakage with both the moss species (Table 3 ). Meanwhile, the terpenoid extracts treated strains such as E. coli, Pseudomonas aeroginosa, and Staphylococcus aureus lost more protein as compared to control cells. The T. tamariscellum extract at the MIC and double the MIC caused significantly more protein leakage in Staphylococcus aureus than the untreated cells. Streptomycinin caused the leakage of high amounts of protein. In the cells treated with DMSO the leakage was marginal i.e., $0.007 \mathrm{mg} / \mathrm{mL}$. These amounts were similar to the untreated cells i.e., $0.0052 \mathrm{mg} / \mathrm{mL}$ of protein was leaked from the cells. The $B$. buchananii extract caused protein leakage at double the MIC was $0.026 \mathrm{mg} / \mathrm{mL}$ against Staphylococcus aureus. The protein leakage observed in the untreated cells was insignificant.

Polyphenols are powerful molecules of disrupting the integrity of the cell wall/membrane like lipopeptides bind to bacteria and cause rapid depolarisation of the membrane and eventual bacterial cell death..$^{30}$ T. tamariscellum extract was capable of causing damage to the $S$. aureus and E. coli membranes resulting in nucleic acid and protein leakage (Figure 1) (Table 3). DMSO did not cause any damage to the membranes as the protein and nucleic acid leakage from the bacterial cells was less. Although the B. buchananii extract caused leakage of nucleic acids and protein in $E$. coli, the leakage was less compared to T. tamariscellum.

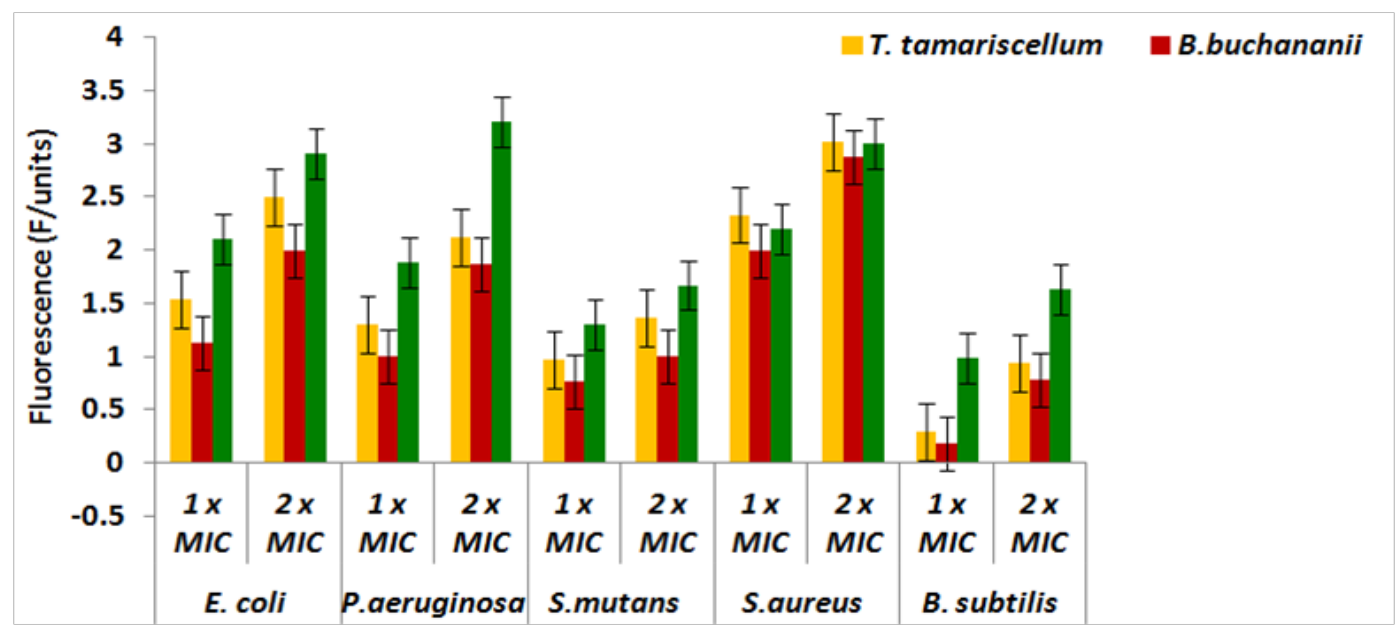

Figure I Fluorescence of PI leakage against selected bacterial strains with T. tamariscellum and B. buchananii terpenoid extracts. 
Table 3 Protein leakage $(\mathrm{mg} / \mathrm{ml})$ against selected bacterial strains with T. tamariscellum and B. buchananii terpenoid extracts

\begin{tabular}{|c|c|c|c|c|c|c|c|c|c|c|}
\hline & \multicolumn{2}{|l|}{ E. coli } & \multicolumn{2}{|c|}{ P. aeruginosa } & \multicolumn{2}{|l|}{ S. mutans } & \multicolumn{2}{|c|}{ S. aureus } & \multicolumn{2}{|c|}{ B. subtilis } \\
\hline & 1xMIC & 2xMIC & 1xMIC & $2 \times \mathrm{MIC}$ & 1 x MIC & $2 \times M I C$ & 1xMIC & $2 \times M I C$ & 1xMIC & $2 \mathrm{MIC}$ \\
\hline T. tamariscellum & 0.023 & 0.031 & 0.02 & 0.028 & 0.014 & 0.021 & 0.03 & 0.048 & 0.009 & 0.012 \\
\hline B. buchananii & 0.019 & 0.025 & 0.015 & 0.02 & 0.01 & 0.018 & 0.026 & 0.037 & 0.005 & 0.009 \\
\hline Streptomycin & 0.025 & 0.036 & 0.024 & 0.03 & 0.018 & 0.025 & 0.032 & 0.0489 & 0.01 & 0.019 \\
\hline
\end{tabular}

\section{Relative electric conductivity of bacterial membrane}

Cell membrane permeability was evaluated in terms of relative electric conductivity. The $\%$ of relative electric conductivity of cells treated with terpenoid extracts demonstrated that $T$. tamariscellum extracts have a positive effect on the membrane permeability of $S$. aureus and E. coli. The terpenoid extracts resulted in increased relative electrical conductivity of bacterial cells, which indicated a leakage of intracellular ingredients especially electrolytes from the cells. The maximum relative permeability were $69 \%$ and $62 \%$ at concentration of $2 \times \mathrm{MIC}$ for $S$. aureus and $E$. coli respectively, that was more than $B$. buchananii terpenoid extracts as shown in the Table 4. Regulating ion homeostasis is essential to the optimal balance of energy level, transport of solutes, regulation of metabolism, turgor pressure control and cell motility, thus a marginal change of the integrity of the membrane structure may influence metabolism and lead to death of the cell. The biomolecules like nucleic acids and proteins were leached from the treated bacteria, an indicator of bacterial cell membrane integrity in comparison to control cells. The overall results of the study suggest the non-recoverable cytoplasmic membranes damage.

Thus, cell membrane integrity was considered as an critical factor to inhibit the growth of bacteria. Further research is warranted to analyze the targeted sites on bacteria cells to make sure that either bactericidal effect was from damage to lipopolysaccharide or membrane proteins in cell wall. Saritha et al. ${ }^{31}$ analyzed the antibacterial mode of action of the alcoholic extracts of Hemidesmus indicus Leucas aspera, Plumbago zeylanica and Tridax procumbens. Pai-Wei Su et al., ${ }^{32}$ displayed similar antibacterial activities mechanism of Polygonum cuspidatum extracts against Nosocomial Drug-Resistant Pathogens. Marasini et al., ${ }^{33}$ evaluated antibacterial activity of ethnic medicinal plants against human pathogenic bacteria. Vandal et al. ${ }^{34}$ screened antimicrobial activity of natural products from the flora of Northern Ontario, Canada. Aboshora et al., ${ }^{35}$ studied the effect of extraction method and solvent power on polyphenol and flavonoid levels in Hyphaene thebaica as antibacterial. Fernando et al. ${ }^{36}$ viewed mode of antimicrobial nanoparticles and mechanisms of action. Wang et al. ${ }^{37}$ role of nanoparticles as antimicrobial agent was confirmed. Bilal Sadiq et al., ${ }^{38}$ proved membrane instability was the major reason of antibacterial activities of Acacia nilotica against Multidrug-Resistant bacteria. Diao et al. ${ }^{12}$ analyzed the chemical composition, antibacterial activity and mode of action of essential oil from seeds of fennel. Bajpai et al., ${ }^{39}$ explained antibacterial mode of action of Cudrania tricuspidata fruit essential oil, affecting membrane permeability and surface characteristics of food-borne pathogens.

Sadiq et al., ${ }^{40}$ screened the phytochemicals and in vitro antibacterial activities of leaves, pods and bark extracts of Acacia nilotica. Borges et al., ${ }^{28}$ proved antibacterial activity and mode of action of ferulic and gallic acids against pathogenic bacteria. Zhao et al., ${ }^{41}$ confirmed antibiotic activity and mechanisms of sugarcane extract against foodborne pathogens. Qader et al., ${ }^{42}$ explained antibacterial activity of plant extracts against clinical pathogens. Mahboubi et al., ${ }^{43}$ isolated phenolic and flavonoid content of Punica granatum flower and validated bactericidal power against bacterial strains causing food borne diseases.

Sonam et $a 1,{ }^{44}$ demonstrated that nanoparticles (NPs) functionalized with essential oils have significant antimicrobial potential against multidrug- resistant pathogens due to an increase in chemical stability and solubility, decreased rapid evaporation and minimized degradation of active essential oil components.

Vidal et al. ${ }^{45}$ screened the secondary metabolites and its synergistic action from the bryophyte Octoblepharum albidum. Bhattarai et al., ${ }^{46}$ proved antioxidant activity of Sanionia uncinata, the artic moss from King George Island, Antarctica. Alam ${ }^{47}$ reviewed Indian bryophytes and their biologically active compounds. Singh et al. ${ }^{48}$ confirmed antimicrobial activity of some Indian mosses. Khanam et al., ${ }^{49}$ validated antibacterial activity of Marchantia palmata. Asakawa ${ }^{50}$ summarized the advances in phytochemistry of bryophytesacetogenins, terpenoids and bis(bibenzyl)s from selected Japanese, Taiwanese, New Zealand, Argentinean and European liverworts. Xie and Lou ${ }^{51}$ screened phytochemicals in bryophytes: an ecological aspect. Bodade et al., ${ }^{52}$ attempted in vitro screening of bryophytes for antimicrobial Activity. Hahn et al., ${ }^{53}$ isolated biaurone, a triflavone and biflavonoids from two Aulacomnium species. Basile et al., ${ }^{54}$ detected antibacterial activity of pure flavonoids isolated from selected mosses. Mukhopadhyay et al., ${ }^{55}$ screened the antimicrobial and antioxidative potential of selected eastern himalayan mosses. Many antibiotics such as oxytetracycline and chlortetracycline, streptomycin, sulfonamides, tylosin, erythromycin, chloramphenicol, and lincomycin are used to control bacterial pathogens worldwide. However, many reports have showed the development of resistant strains in the isolates. Bryophytes chemically synthesize wide terpenoids, phenolics as microbicidal against fungi and prokaryotes. In this study, the microbicidal activities of bryophytes were tested for the first time in the literature against Gram positive, Gram negative and fungal species. The terpenoids of these bryophytes may be used as an alternative to the regular antibiotics. All the above works substantiates the microbicidal potential of the moss species obtained in the present study.

\section{Fungal spore inhibition assay}

Figure 2 shows the effect of T. tamariscellum and B. buchananii terpenoid extracts on spore germination against fungal pathogens like C. albicans and A. flavus. Both the extracts showed significant 
inhibition against the two tested fungi. Spore germination of $C$. albicans and A. flavus was inhibited to 76 and $72 \%$ by T. tamariscellum extract. Similarly, B. buchananii terpenoid extract was also equally effective. For pathogenic fungi, spore germination is an optimal factor at the onset of their colonization, and the tested extracts have a definite potential, which can be used as a new potential fungicide. The assay values further substantiates the zone of inhibition, MIC and MKC values. Most Ferdousi Begum et al. ${ }^{56}$ analyzed spore and mycelial growth inhibition of three fruit rot pathogens using some synthetic fungicides and botanical extracts. Silva et al., ${ }^{57}$ studied fungicidal activity of medicinal plant extracts against pathogens of coffee. Awad and $\mathrm{Baka}^{58}$ reported the herbal extract control of the fungi associated with different Egyptian wheat cultivars grains.

Table 4 Relative electric conductivity (\%) against selected bacterial strains with T. tamariscellum and B. buchananii terpenoid extracts

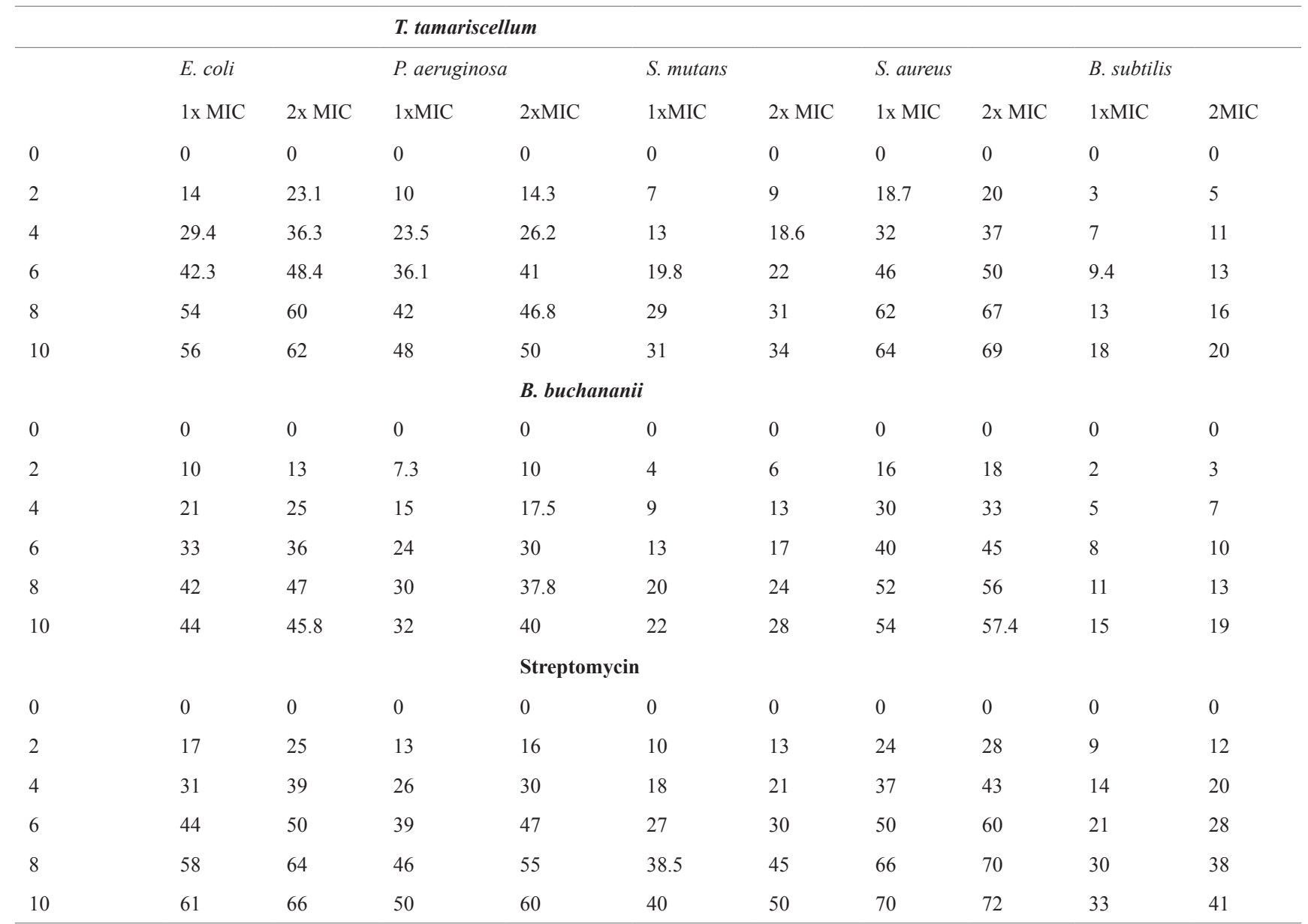

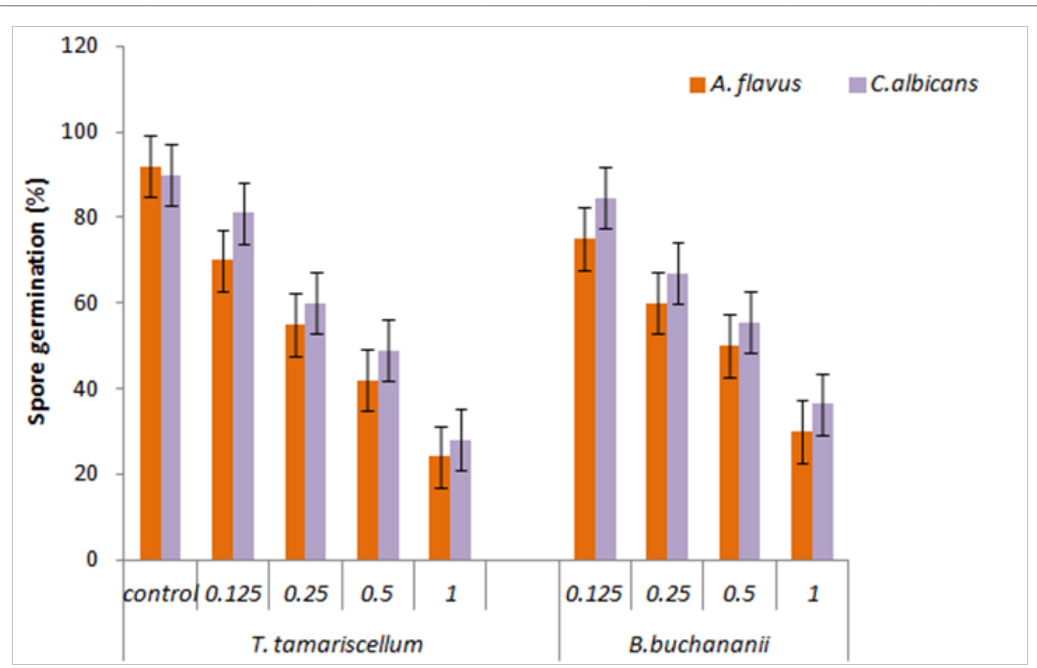

Figure 2 Spore inhibition assay against selected fungal strains using T. tamariscellum and B. buchananii terpenoid extracts. 


\section{Conclusion}

Based on the present research, the T. tamariscellum and $B$. buchananii terpenoid extracts displayed a optimal microbicidal activity against $S$. aureus and $E$. coli. Terpenoid extracts caused the alterations in the cell wall and membrane of the pathogens. As per the results, the mode of action against $S$. aureus and E. coli may be membrane break through the permeability of cell membrane, and then led to the leakage of electrolytes, proteins and DNA. These changes resulted in to cell death eventually, which were corresponded to a simultaneous reduction in the number of viable cells. However, because of the heterogeneous compositions, it seems unlikely that there is more than one mode of action responsible for the antimicrobial action. Therefore, further research is warranted to understand the modes, such as the inhibition of pathogens, the interactions with other ingredients in order to justify the real applications of terpenoid in practices as a natural microbicidal agent. Bryophyte species are unexplored and may be an alternative effective approach because of their safety, relatively low cost and effectiveness against pathogens.

\section{Acknowledgements}

This study was supported by the Junior Research Fellowship from the CSIR-UGC, New Delhi, India (Sr.No.2121530797, Ref. No.20/12/2015).

\section{Conflict of interest}

The author declares that there is no conflict of interest.

\section{References}

1. Mishra R, Pandey VK, Chandra R. Potential of bryophytes as therapeutics. Int J Pharm Sci Res. 2014;5(9):3584-3593.

2. Chobot V, Kubicova L, Nabbout S, et al. Evaluation of antioxidan activity of some common moss species. Zeitschrift fur Natur for schung. 2008;63(7):476-482.

3. Gokbulut A, Satilmis B, Batcioglu K, et al. Antioxidant activity and luteolin content of Marchantia polymorpha L. TurkJ Bot. 2012;36:381-385.

4. Manoj GS, Murugan K. Phenolic profiles, antimicrobial and antioxidant potentiality of methanolic extract of a liverwort, Plagiochilla beddomei steph. Ind J Nat Prod Res. 2012;3(2):173-183.

5. Hallingback T, Hodgetts N. World Conservation Union; (Mosses, Liverworts, and Hornworts. Status Survey and Conservation Action Plan for Bryophytes). 2000

6. Nikolajeva V, Liepina L, Petrina Z, et al. Antibacterial activity of extracts of extracts of some bryophytes. Adv Microbiol. 2012;2(3):345-353.

7. Olofin TA, Akande AO, Oyetayo VO. Assessment of the antimicrobial properties of fractions obtained from bryophytes. J Microbiol Antimicrob. 2013;5(5):50-54.

8. Sabovljevic AM, Sokovic J, Glamoclija A, et al. Bio activities of extracts from some axenically farmed and naturally grown bryophytes. $J \mathrm{Med}$ Plants Res. 2011;5(4):656-671.

9. Ferguson NM. A text book of pharmacognosy. MacMilan company: New Delhi; 1956

10. Performance standards for antimicrobial disk susceptibility tests. 5th edition. National committee for clinical laboratory standards. NCCLS: Villanova; 1993.
11. Eloff JN. A sensitive and quick microplate method to determine the minimal inhibitory concentration of plant extracts for bacteria. Planta Medica. 1998;64(8):711-713.

12. Diao WR, Hu QP, Zhang H, et al. Chemical composition, antibacterial activity and mechanism of action of essential oil from seeds of fennel (Foeniculum vulgare Mill.). Food Control. 2014;35:109-116.

13. Du W, Sun C, Liang Z, et al. Antibacterial activity of hypocrellin A against Staphylococcus aureus. World J Microbiol Biotechnol. 2012; 28(11):31513157.

14. Bradford MM. A rapid and sensitive method for the quantitation of microgram quantities of protein utilizing the principle of protein-dye binding. Anal Biochem. 1976;72(1-2):248-254.

15. Ibrahim M, Shehu K, Tafinta IY, et al. Efficacy of some plant extracts on growth and germination of Rhizopus stolonifer and Fusarium oxysporum isolated from rotten Irish potato tubers. Ann Biol Sci. 2014;2(3):63-67.

16. Salhi N, Mohammed Saghir SA, Terzi V, et al. Antifungal activity of aqueous extracts of some dominant. Algerian Med Plants Biomed Res Int. 2017;2017:7526291.

17. Martins CM, Nascimento EA, Morais SAL, et al. Chemical constituents and evaluation of antimicrobial and cytotoxicity activities of Kielmeyera coriacea Mart. \& Zucc.Essential oils. Evide Based Compl Alternat Med. $2015 ; 1-9$.

18. Patil SJ, Venkatesh S, Vishwanatha T, et al. GC-MS analysis of bioactive constituents from the petroleum ether extract of Citrus medica seeds. World J Pharma Pharm Sci. 2014;3(2):1239-1249.

19. Laura Klavina, Gunta Springe, Vizma Nikolajeva, et al. Chemical composition analysis, antimicrobial activity and cytotoxicity screening of moss extracts (Moss Phytochemistry). Molecules. 2015;20(9):1722117243

20. Pejin B, Bogdanovic-Pristov J, Pejin I, et al. Potential antioxidant activity of the moss Bryum moravicum. Natural Product Research. 2013;27(10):900-902.

21. Weerakkody NS, Caffin N, Turner MS, et al. In vitro antimicrobial activity of less-utilized spice and herb extracts against selected food-borne bacteria. Food Control. 2010;21(10):1408-1414.

22. Aligiannis N, Kalpoutzakis E, Mitaku S, et al. Composition and antimicrobial activity of the essential oils of two Origanum species. J Agri Food Chem. 2001;49(9):4168-4170.

23. Irfan, Shakeel Ahmed, Manik Sharma. Antimicrobial activity of terpenoids from Sphaeranthus indicus. L. Asian J Plant Sci Res. 2014;4(1):1-6.

24. Singh B, Singh S. Antimicrobial activity of terpenoids from Trichodesma amplexicaule Roth. Phytother Res. 2003;17(7):814-816.

25. Lv F, Liang H, Yuan Q, et al. In vitro antimicrobial effects and mechanism of action of selected plant essential oil combinations against four foodrelated microorganisms. Food Res Int. 2011;44(9):3057-3064.

26. Wu VCH, Qiu X, de los Reyes BG, et al.Application of cranberry concentrate (Vaccinium macrocarpon) to control Escherichia coli $\mathbf{O 1 5 7 : H 7}$ in ground beef and its antimicrobial mechanism related to the down regulated slp, hdeA and cfa. Food Microbiol. 2009;26(1):32-38.

27. Carson CF, Mee BJ, Riley TV. Mechanism of action of Melaleuca alternifolia (tea tree) oil on Staphylococcus aureus determined by time-kill, lysis, leakage and salt tolerance assays and electron microscopy. Antimicrob Agents Chemother. 2002;46(6):1914-1920.

28. Borges A, Ferreira C, Saavedra MJ, et al. Antibacterial activity and mode of action of ferulic and gallic acids against pathogenic bacteria. Microb Drug Resist. 2013;19(4):256-265. 
29. Palmer J, Flint S, Brooks J. Bacterial cell attachment, the beginning of a biofilm. J Ind Microbiol Biotechnol. 2007;34(9):577-588.

30. Batanai Moyo, Stanley Mukanganyama. Antibacterial effects of Cissus elwitschii and Triumfetta welwitschii extracts against Escherichia coli and Bacillus cereus. Int J Bacteriol. 2015;162028.

31. Saritha K, Rajesh A, Manjulatha K, et al. Mechanism of antibacterial action of the alcoholic extracts of Hemidesmus indicus (L.) R. Br. ex Schult, Leucas aspera (Wild.), Plumbago zeylanica L., and Tridax procumbens (L.) R. Br. ex Schult. Front Microbiol. 2015;6:577.

32. Pai-Wei Su, Cheng-Hong Yang, Jyh-Ferng Yang, et al. Antibacteria activities and antibacterial mechanism of Polygonum cuspidatum extracts against nosocomial drug-resistant pathogens. Molecules. 2015;20(6):11119-11130.

33. Marasini BP, Baral P, Aryal P, et al. Evaluation of antibacterial activity of some traditionally used medicinal plants against humanp pathogenic bacteria. Biomed Res Int. 2015:6.

34. Vandal J, Abou-Zaid MM, Ferroni G, et al. Antimicrobial activity of natural products from the flora of Northern Ontario, Canada. Pharm Biol. 2015;53(6):800-806.

35. Aboshora W, Lianfu Z, Dahir M, et al. Effect of extraction method and solvent power on polyphenol and flavonoid levels in Hyphaene thebaica L. Mart (Arecaceae) (Doum) Fruit, and its antioxidant and antibacterial activities. Trop J Pharm Res. 2014;13:2057-2063.

36. Fernando SSN, Gunasekara TDCP, Holton J. Antimicrobial nanoparticles: applications and mechanisms of action. Sri Lankan J Infect Dis. 2018;8(1):2-11.

1.

37. Wang $\mathrm{L}, \mathrm{Hu} \mathrm{C}$, Shao L. The antimicrobial activity of nanoparticles: presen situation and prospects for the future. Int J Nanomed. 2017;12:1227-1249.

38. Bilal Sadiq M, Tarning J, Aye Cho TZ, et al. Antibacterial activities and possible modes of action of Acacia nilotica (L.) Del. against multidrugresistant Escherichia coli and Salmonella. Molecules. 2017;22(47):1-18.

39. Bajpai VK, Sharma A, Baek KH. Antibacterial mode of action of Cudrania tricuspidata fruit essential oil, affecting membrane permeability and surface characteristics of food-borne pathogens. Food Control. 2013;32(2):582-590.

40. Sadiq MB, Hanpithakpong W, Tarning J, et al. Screening of phytochemicals and in vitro evaluation of antibacterial and antioxidant activities of leaves, pods and bark extracts of Acacia nilotica (L.) Del. Ind Crops Prod. 2015;77:873-882.

41. Zhao Y, Chen M, Zhao Z, et al. The antibiotic activity and mechanisms of sugarcane (Saccharum officinarum L.) bagasse extract against food-borne pathogens. Food Chem. 2015;185:112-118.

42. Qader MK, Khalid NS, Abdullah AM. Antibacterial activity of some plant extracts against clinical pathogens. Int J Microbiol Immunol Res. 2013;1(5):53-56.
43. Mahboubi A, Asgarpanah J, Sadaghiqani PN, et al. Total phenolic and flavonoid content and antibacterial activity of Punica granatum L. Var. pleniflora flower (Golnar) against bacterial strains causing food borne diseases. BMC Complem Altern Med. 2015;15:366-373.

44. Sonam Chouhan, Kanika Sharma, Sanjay Guleria. Antimicrobial activity of some essential oils-present status and future perspectives. Medicines. 2017;4(3):58.

45. Vidal CAS, Sousa EO, Rodrigues Fabiola FG, et al. Phytochemical screening and synergistic interactions between aminoglycosides, selected antibiotics and extracts from the bryophyte Octoblepharum albidum Hedw (Calymperaceae). Arch Biol Sci. 2012;64(2):465-470.

46. Bhattarai, HD, Paudel B, Lee HS, et al. Antioxidant activity of Sanionia uncinata, a polar moss species from King George Island, Antarctica. Phytother Res. 2008;22(12):1635-1639.

47. Alam A. Some Indian Bryophytes known for their biologically active compounds. Int J ApplBiol and Pharm Tech. 2012;3(2):239-246.

48. Singh M, Rawat AKS, Govindarajan R. Antimicrobial activity of some Indian Mosses. Fitoterapia. 2007;78(2):156-158.

49. Khanam R, Chaudhary BL, Khanam S, et al. Antibacterial activity of Marchantia palmate Nees. J Biol \& Pharm Res. 2011;1(2):27-36.

50. Asakawa Y. Recent advances in phytochemistry of bryophytesacetogenins, terpenoids and bis(bibenzyl)s from selected Japanese, Taiwanese, New Zealand, Argentinean and European liverworts. Phytochem. 2001;56(3):297-312.

51. Xie CF, Lou HF.. Secondary metabolites in bryophytes: An ecological aspect. Chem Biodiver. 2009;6(3):303-312.

52. Bodade RG, Borkar PS, Arfeen S, et al. In vitro Screening of bryophytes for antimicrobial activity. $J$ Med Plants. 2008;7(4):310-319.

53. Hahn H, Seeger T, Geiger H, et al. The first biaurone, a triflavone and biflavonoids from two Aulacomnium species. Phytochem. 1995;40(2):573576.

54. Basile A, Giordano S, Lopez-Saez JA, et al. Antibacterial activity of pure flavonoids isolated from mosses. Phytochem. 1999;52(8):1479-1482.

55. Mukhopadhyay ST, Mitra S, Nilansu Das AB, et al. Screening of antimicrobial and antioxidative potential of selected eastern himalayan mosses. European J MedPlants. 2013;3(3):422-428.

56. Most Ferdousi Begum, Mst Ferdowsi Mahal, Md Shahidul Alam. Inhibition of spore germination and mycelial growth of three fruit rot pathogens using some chemical fungicides and botanical extracts. J Life Earth Sci. 2010;5:23-27.

57. Silva JL, Souza PE, Monteiro FP, et al. Antifungal activity using medicinal plant extracts against pathogens of coffee tree. Rev Bras Pl Med Campinas. 2014;16(3):539-544.

58. Awad Z, Baka M. Plant extract control of the fungi associated with different Egyptian wheat cultivars grains. J Plant Pro Res. 2014;54(3):231-237. 